\title{
Dogs and Coca-Cola: Commemorative Practices as part of Laboratory Culture at the Heymans Institute Ghent, 1902-1970
}

\author{
TRUUS VAN BosSTRAETEN*
}

\begin{abstract}
This article investigates the different dimensions and the attributed meaning of commemoration as essential parts of laboratory culture. Rather than a historical ethnography of commemorative rites, commemoration is studied as a genuine component of laboratory life. The case study focuses on the Heymans Institute of Ghent University, Belgium, from 1902 to 1970. Using the categories celebrations, publications and iconography it will become clear that the Heymans lab and by extension many other laboratories performed a multitude of commemorative practices all with their specific function both inside and outside the lab. Not only public celebrations for the successful laboratory director, but also, for example, birthday parties are taken into account. How did these practices evolve throughout time? What images did they convey and what did they mean for the laboratory? The answer to the questions in hand will contribute to a further understanding not only of the concept of commemorative practices but also of laboratory life and - culture in general.
\end{abstract}

Keywords. Heymans, commemorative practices, laboratory culture, family, school

\section{Introduction}

When you enter the main room of the Heymans Foundation, located on the first floor of the present Pharmacology Institute at Ghent University in Belgium, the omnipresence of Jan Frans Heymans and his son Corneel is overwhelming. Wooden cabinets and glass showcases filled with memorabilia, medals and decorations, photo albums, manuscripts, publications and personal archival material are aligned against the walls. The walls themselves are almost completely covered with framed diplomas, paintings, caricatures, group pictures and portraits. Even Jan Frans' tobacco pouch and Corneel's typewriter are on display.

Both father and son Heymans were world-renowned pharmacologists with a strong physiological interest. They jointly initiated the research on the carotid sinus for which Corneel Heymans obtained the Nobel Prize in 1938, 6 years after the death of his father. The Heymans Foundation (1969-1971) was established by André De Schaepdryver, one

\footnotetext{
*Department of Cultural History, Blijde Inkomststraat 21, pb 3307, Leuven 3000, K. V. Leuven, Belgium. E-mail: truus.vanbosstraeten@arts.kuleuven.be
} 
of Corneel Heymans successors who wanted to keep the memory of the two remarkable scientists alive. During a conversation at the Heymans Institute, De Schaepdryver explained to me why the room where the foundation is located breathes the atmosphere of another era: 'You can see the difference [in comparison to the rest of the building] too, it's like a Hilton this room, I mean, the walls and all...I wanted to preserve a bit of the atmosphere of the old institute, the conviviality' (DSI). ${ }^{1}$ De Schaepdryver stressed the contrast between the concrete walls and clean environment of the new lab and the warm familiar surroundings of the old institute. He added that after the death of Corneel Heymans in 1968 and the relocation of the lab to a new building in 1972, the old convivial atmosphere gradually faded away. During the talk it became clear that De Schaepdryver regretted most of all the diminished social cohesion of the group.

Looking around the room, I seemed to witness an accumulation of material marking a century long commemoration of the great Jan-Frans Heymans (1859-1932) and his famous Nobel Prize winning son Corneel (1892-1968). After a few days of 'digging' in the armoires filled with albums and boxes, I found three photo albums put together by pharmacist Miss Henriette Casier, who worked at the Institute from 1930 to 1969. Apparently over four decades Miss Casier managed to capture various aspects of laboratory life on her camera and then transfer these to the albums: the building, the people and their activities. She inserted a picture of every member of the laboratory group, whether it was a student assistant, a cleaning lady or a visiting scholar. Page after page her careful handwriting indicated: 'my desk', 'the cleaning and technical staff', 'retirement party' and so forth. Most of the actual pictures, however, were missing. Some of them had made it to a big Heymans' album on display with no reference to their provenance, but the majority were just stuffed into a folder labeled 'leftovers collection Casier' that was to be found in a dark corner of another cabinet. Aside from the rather predictable story of the forgotten scientists working in the shadow of the lab's leading star, something else came to my mind. Was it — given the content of the albums - a lab custom to commemorate local events and group members? Was this a different kind of commemoration than the one on display and what did it mean?

The death, birthday or retirement of a famous scientist or the anniversary of an important scientific institute, are recurrent occasions for commemorative practices (AbirAm, 1998b, p. 27). Several historians of science have explored the different dimensions of commemorative practices and have shown that they mean much more than the tribute or homage that legitimize their organization. ${ }^{2}$ On the one hand, for new scientific disciplines the adherence to a universally acknowledged hero or founding father honored in commemorations is vital in the creation of a professional identity. This kind of commemorative activity on behalf of a hero scientist is generally bathes in an atmosphere of nostalgia, when the good, altruistic scientist is honored at the end of a successful career despite difficult beginnings in an era when everything was different (Abir-Am, 1999c). For individual scientists, on the other hand, organizing or partaking of commemorations means that they place themselves in a tradition, often an 'invented tradition' constructed 
to suit their need to legitimize themselves. Scientists secure a place for themselves in the genealogy of their discipline and so create the chance to affirm their own agendas for the new generation. Remembering a successful past is a way of securing the future.

Commemorative practices are generally divided into three types depending on the object or subject of commemoration: disciplinary, institutional and personal. This means that commemoration may be used to construct a disciplinary identity, to put institutions on the scientific map or to celebrate a particular scientist, a cultural hero. ${ }^{3}$ Studies of commemoration in science, such as those carried out by Pnina Abir-Am, Dominique Pestre and others, often aim to contribute to the creation of a historical ethnography of commemorative rites. They also tend to explore the theoretical foundations of the concept of commemorative practices as well as the historicity, cultural context, disciplinary specification and political use of commemorations (Abir-Am, 1998a, p.13). Countercommemorative works, on the other hand, intend to revise scientific legends and are in turn studied as homages to 'what really happened', the 'true story of a genius or a discovery' (Sinding, 1998b).

What seems to be missing, however, is the study of commemorative practices in the context of laboratory culture. This article will consider commemoration as an essential part of laboratory life. Therefore it addresses the different dimensions and attributed functions and meanings of commemorative practice in the laboratory context. Following Robert Kohler's suggestion (2008) the lab is studied as a social and cultural infrastructure. This discussion therefore considers a variety of practices used to commemorate, remember or celebrate different members of the laboratory group or the institute itself. From the following text it will become apparent that rather than being the peculiar practice of a bunch of scientists working together, commemoration in the context of the Heymans' laboratory was a multi-layered and recurrent phenomenon that served to reconcile different identities and functions of the lab: the 'school-like' atmosphere created by having one visible 'master' with the 'family feeling' created by a group of people working closely together as a team. Commemorative practices, both public and private, were an important tool in constructing a complex laboratory identity in a changing scientific world full of seemingly irreconcilable features. It will become clear that commemorative practices were key elements in the 'social enterprise' that the modern laboratory turned out to be (Todes, 2002, p. xiv).

The Heymans Institute makes an interesting and exemplary case for several reasons. During the period studied here, 1902-1970, it was an internationally renowned centre of pharmacology and physiology with a network that expanded from the United States to Russia and Japan. ${ }^{4}$ The institute was however located in a small country with a less prominent scientific tradition than neighbors such as France or Germany, so it also has common grounds with other scientifically 'peripheral' countries. ${ }^{5}$ But more than the intermediary position of the lab, it was the unique nature of the source materials that influenced my decision to develop this case study. During my research on other Belgian academic laboratories, I found several clues to similar commemorative traditions 
but never were they so amply documented. ${ }^{6}$ The numerous albums of the Heymans Institute with pictures from the early 20th century onwards and the different events they commemorate-birthday parties, anniversaries, jubilees etc.-are extraordinary diachronic sources because they not only allow a 'sneak peak' into the private life of the laboratory but also because they visually portray commemoration as a multi-facetted concept: Nobel banquets in honor of Corneel Heymans and jubilees of care-takers, they are all there.

The case-study consists of three parts. First I will introduce both Heymans and their institute in order to outline the development of the laboratory - a laboratory that ended up commemorating not only its scientific leader but each and every person of its small community. Here the lab will also be placed in a broader international scientific context. This introduction will be followed by a discussion of the commemorative practices which is broken down into two separate parts: one that addresses private commemoration and another that looks at commemorative practices performed with a broader audience in mind. The private or internal commemorative practices were in-house, small scale and only accessible for the laboratory group and their family members. The denomination 'official' or 'public' indicates the commemorative practices organized by the laboratory for a wider public than the laboratory group itself. In both instances, three types of commemorative practices are analyzed: celebrations, publications and iconography.

The overall approach of this article differs from traditional historiography of commemorative practices on a number of levels. First, and most importantly, it studies commemoration as part of laboratory life and not as something 'extra muros'. Second, the organizing principle is not the object or subject of commemoration, but rather the nature of the practices in relation to the public they address: private or public, informal or formal. Third, and in connection to the previous point, the new category of 'internal commemoration' is introduced and thoroughly analyzed both as a separate entity and in relation with the commonly studied 'official commemoration'.

\section{The Father, the Son and the Laboratory}

Jan Frans Heymans (1859-1932) was a farmer's son who got into high school and college by means of several scholarships. He obtained a degree in natural science (1884) and medicine (1887) at the University of Leuven. After the successful completion of his science studies, Jan Frans Heymans won a travelling grant with his dissertation. This enabled him to work for a few months at the Parisian Collège de France in the lab of histologist Louis Antoine Ranvier, a former assistant to Claude Bernard. ${ }^{7}$ Equally important as his research in Paris, were the people he met, such as Louis Pasteur, Eugène Gley and Charles Richet. Like many of his contemporaries, J. F. Heymans built the foundations of his future scientific network during his Wanderjahre. In particular the contact with Gley would later prove to be very helpful as Gley supported 


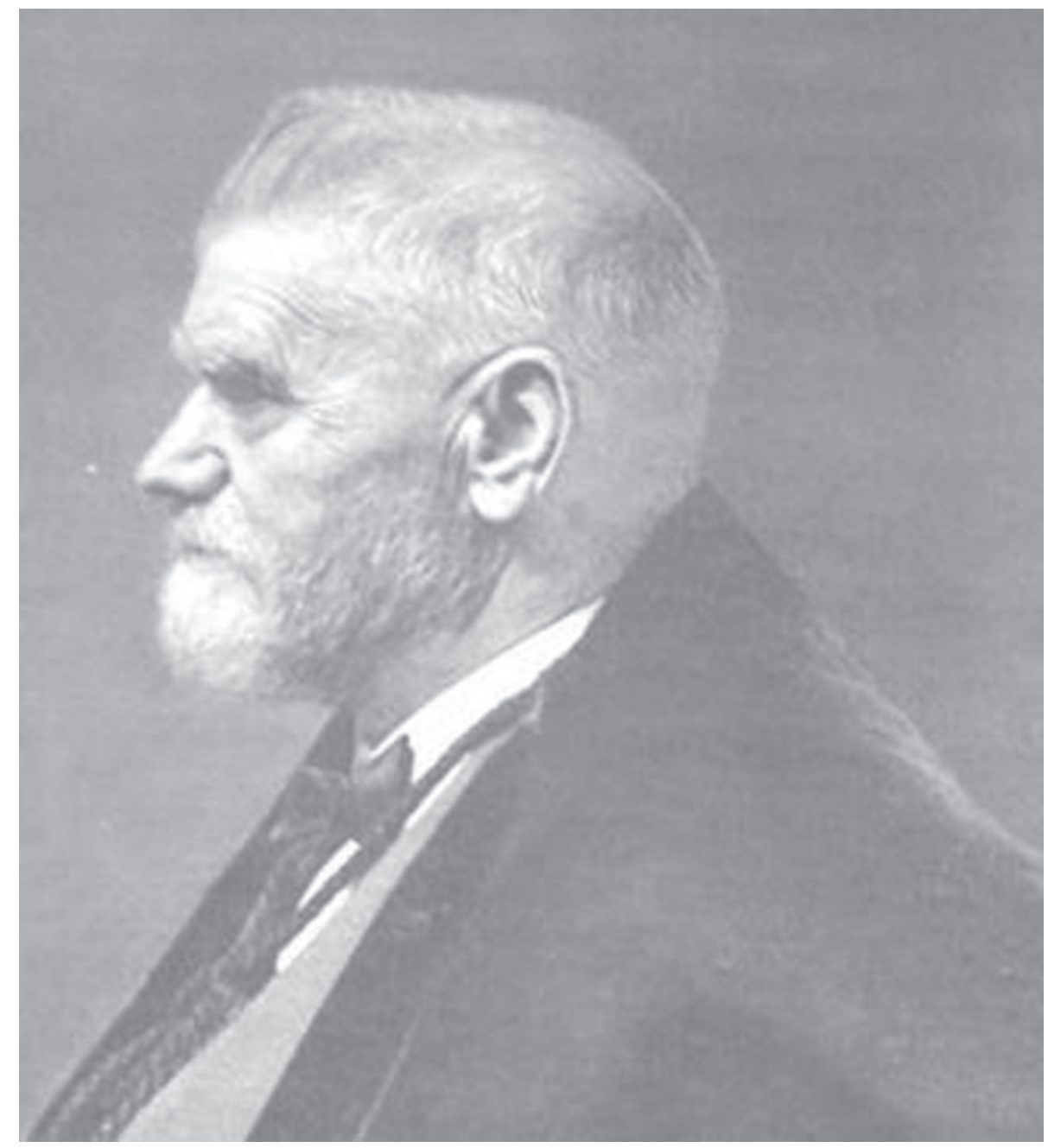

Fig. 1. Portrait of Jan Frans Heymans, 1925.

Heymans' idea to found a journal and became co-editor of the Archives Internationales de Pharmacodynamie et de Thérapie in 1895 (Tiffeneau, 1933). After his stay in Paris, Jan Frans Heymans returned to Leuven to study medicine and organic chemistry. He graduated in 1887 and obtained a position as an assistant to physiologist Emil du BoisReymond in Berlin.

Heymans' broad background and experience in France and Germany made him the perfect candidate for Belgium's first chair of pharmacodynamics and therapeutics at the State University of Ghent. He accepted the position in 1890 upon the condition that he could have at his disposal a fully equipped research laboratory. ${ }^{8}$ More than a decade 
later, in 1902, Heymans could finally move into the new Institut de Pharmacodynamie et de Thérapie. The institute, once described as a 'palais de crystal' or 'crystal palace' by Parisian chemist Marc Tiffeneau (Heymans et al., 1932, p. 24), was the pride of J. F. Heymans. It was constructed according to the director's design and the glass paneled laboratory materialized his ideal of an airy workspace perfectly adapted to a cohesive research group: 'Maximum light, minimum distance; complete separation between the rooms for theoretical education and practical courses; and to conclude maximum community feel between the researchers in the labs' (Heymans, 1932, p. 34). ${ }^{9}$ The institute was truly one of a kind and was greatly admired in Belgium and abroad. When Liège physiologist Léon Fredericq (1851-1935)—he and J. F. Heymans were counted among the giants of biological research according to American physiologist Carl Wiggers (1958, p. 132)_visited the Ghentian institute, he was so impressed he supposedly said he would torch his own institute in order to obtain the same magnificent building (Heymans, 1932, p. 34).

Another reason for the airy design was aptly and probably more realistically described by Carl Wiggers: 'Individual laboratories were separated by glass partitions and so spaced that the Director in his office could keep work and workers under surveillance. Père Heymans remarked that he believed in relaxation and recreation, but that he firmly held that the laboratory is a place for work' (Wiggers, 1958, p. 133). During the first decades of the 20th century, the staff of the Institute grew from a small group of student-assistants, caretakers and technicians to an elaborate research group. Jan Frans Heymans was lord and master of his Institute and bent the university rules to his own needs. He protected his personnel when they were sick, but expected them to work long shifts and late nights, even on Sundays. Consequently he had numerous disputes with the University administrators because they accused him of abusing his personnel and disrespecting regulations. Heymans, on the other hand, pleaded for self-governance of his 'laboratory household'. ${ }^{10}$ Thus father Heymans adhered to the family or household metaphor, which will be discussed later on as an important theme in commemoration, in a clear paternalistic manner.

Under Jan Frans Heymans research was focused around his favorite topics: bovine tuberculosis and the regulatory mechanisms of respiration and blood pressure. The first research direction mostly gained him national fame as he set up many large-scale vaccination programs for live stock (DSI). Regarding the circulation research, Heymans and co-worker Kochmann developed a method to keep an isolated heart working by means of a connection with another body (1904). Later, with De Somer in 1911, Heymans took the circulation research a step further and he developed the complicated crossed head or isolated head technique, by which the head of one dog was connected to the body of another and vice versa. The technique could be used on other mammals and together with Jan Frans' earlier method of cross-circulation of the heart it proved very useful for other pharmacological and physiological research as well as clinical applications. Heymans' circulation methods are cited as recently as $2003 .{ }^{11}$ 


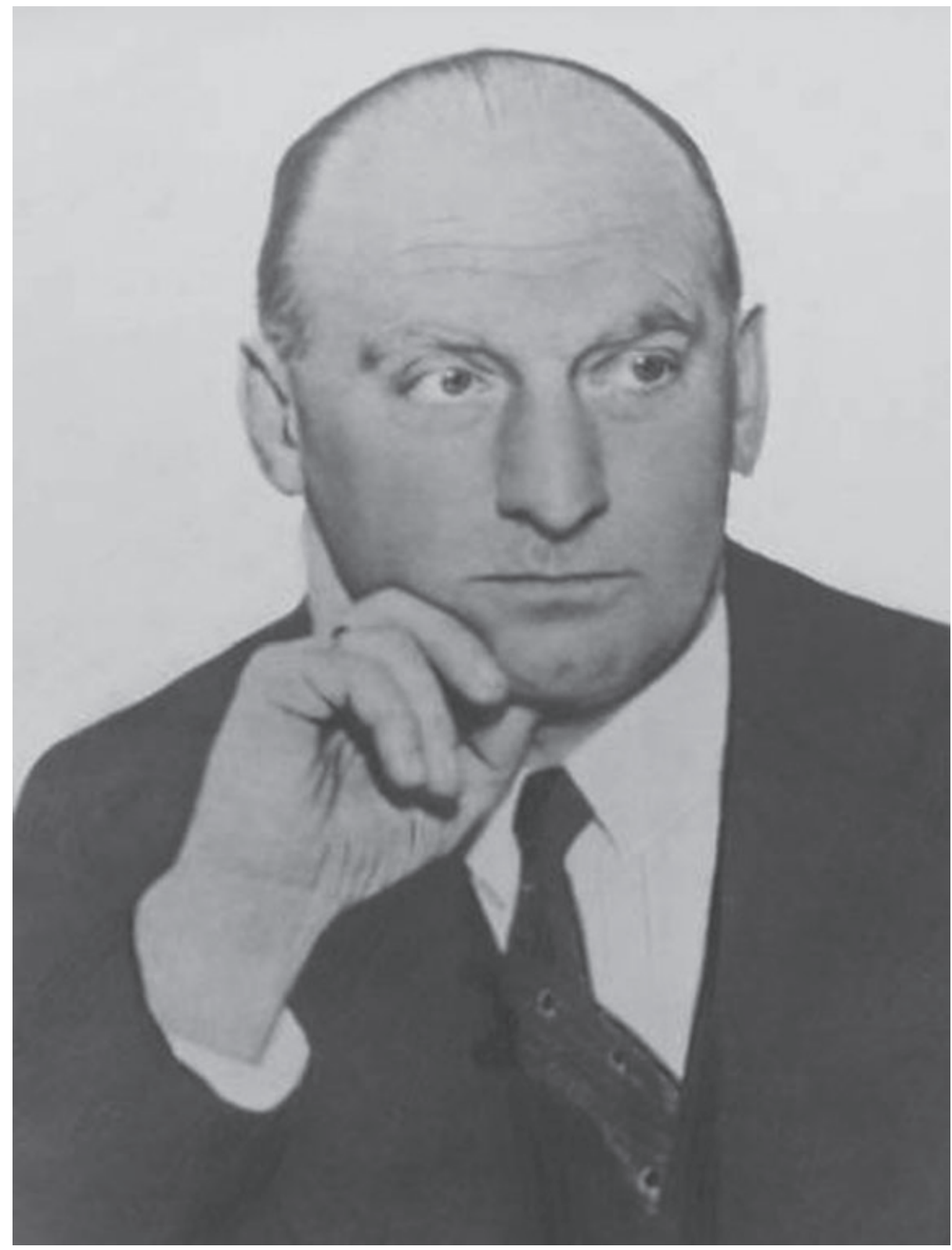

Fig. 2. Portrait of Corneel Heymans 'head-on-hand pose', s.d.

In 1912, around the time the new crossed head technique was introduced in the lab, Corneel Heymans, Jan Frans' oldest son enrolled in medical school. He had hardly entered his father's laboratory as a young student, when World War One broke out 
and the institute closed for 2 years. The young Heymans obtained his medical degree in 1920 and subsequently worked in laboratories all over the world: i.e. at Collège de France with Eugène Gley and at Western Reserve Medical School with Carl Wiggers (Nobel Foundation, 1965; Florquin, 1974). In 1922 Corneel Heymans became lecturer in Pharmacology at Ghent University and thus a staff member at his father's institute. Despite the fact that the institute flourished after the war and attracted an increasing number of Belgian and foreign researchers, the University did not create a new tenure research position for Corneel Heymans. The difficulties in obtaining a permanent position at Ghent University turned out to be a blessing since they had spared the young Heymans from the inevitable administrative and other obligations that come with the direction of a lab and so gave him ample time to visit and work abroad (Heymans, 1963b). The paternalistic attitude of Jan Frans Heymans, however, did not spare his son. When Carl Wiggers visited the institute in 1927, he recalled father Heymans yelling through the entire lab: 'don't hesitate to make my son work hard when he comes to visit you in Cleveland!' $(1958,135)$. His son was 35 at that time and had already proven himself to be a diligent worker and a creative thinker in several publications.

Corneel Heymans eventually was given tenure when his father denounced part of his educational charge. In 1930 Jan Frans Heymans completely passed the torch on to his son (De Schaepdryver and Bogaert, 1998). Corneel became director of the institute and obtained the full chair of pharmacology. By then, father and son had jointly refined the isolated head technique (Heymans and Heymans, 1927). Jan Frans and Corneel Heymans were also considered to be 'the two most important researchers in cardiorespiratory physiology' between 1920 and1930 along with Heinirch Hering at Köln (De Castro, 2009b). When Jan Frans Heymans died in 1932, he was acknowledged as a great physiologist and pharmacologist. For weeks condolences from all over the world reached the institute. Although it is common to speak nothing but good about the deceased, these heart felt letters, which included ones from Pavlov in Leningrad, Wenckebach in Vienna, Tiffeneau in Paris, Barcroft in Cambridge and Abel in Baltimore indicated that Heymans was both an internationally recognized scholar and a good friend to many. ${ }^{12}$

In close collaboration with his team members, Corneel Heymans continued the studies he had begun with his father. This resulted in highly discussed papers and a book on the carotid sinus (Heymans, Bouckaert and Dautrebande, 1930, 1931; Heymans et al., 1932; Heymans, Bouckaert and Regniers, 1933). The discovery of the role played by the sinus and aortic mechanisms in the regulation of respiration earned him the Nobel Prize in 1938. Heymans' attachment to the isolated head technique did not, however, prevent the research group at the pharmacology institute, now counting about six full time appointed researchers, investigating a wider variety of pharmacological and physiological topics such as the determination of alcohol levels in the blood. ${ }^{13}$ Corneel Heymans, as his father, led the lab is if it were his own family. He was severe and even harsh when it came down to science, but he was warmhearted and approachable as a person. $\mathrm{He}$ was less distant than his father and pursued an informal atmosphere in the lab. ${ }^{14}$ After 
several personal tragedies-he lost his oldest son in 1940 and was falsely accused of collaboration after World War II-Corneel Heymans became even more attached to his 'laboratory family'(Fox, 1994, p. 85).

The Nobel Prize and the ground-breaking research preceding the award brought Heymans' career to another level. The institute had always been internationally orientated but being the home of a Nobel Prize laureate, it began to attract more researchers from abroad (De Schaepdryver, 1990, pp. 69-70). It became a true 'Mecca' for students and researchers from foreign countries (Wiggers, 1958, p. 133). The fame of Corneel Heymans and the international atmosphere were the main attractions of the lab, rather than the complicated techniques he developed (DSI). Hence a core staff, composed of permanent researchers, technicians and maintenance personnel, was regularly complemented with visiting scholars and students. At the end of his career Corneel Heymans had published about 800 papers and almost 150 researchers had come to work in the lab (De Schaepdryver, 1972, p. 25).

Corneel Heymans participated in numerous international missions on behalf of the Belgian government, the World Health Organization (WHO) and as president of the International Physiological Society. During one of his WHO missions, in 1953 to India, Heymans became close friends with Alexander Flemming. 'Corney' and 'Flem' frequently wrote to each other during the subsequent years. ${ }^{15}$ According to Renée Fox, an American sociologist who studied Belgian medical research from the late 50s onwards, Heymans deeply cherished his friendships with Sidney Farber and other 'distinguished medical scientists like Sir Alexander Fleming, Ernst Chain, Daniel Bovet and Alexis Carrel' (1994, p. 82). By the end of his career Corneel Heymans had clearly become 'a teacher, consultant, and statesman of medical science and research all over the world' (Fox, 1994, p. 75). The holder of 15 Honorary doctorates, many more degrees and decorations, Corneel Heymans died in 1968, 5 years after he became Professor emeritus (De Schaepdryver, 1972, pp. 26-30). He had lived to see the foundations arise of a new institute of pharmacology located near the university hospital. Four years after his death, the laboratory group now headed by André De Schaepdryver, moved into the new building. It was the so-called end of an era (DSI).

\section{Private Commemorative Practices: Confirmation of a Family Ideal}

From the above introduction it is apparent that Jan Frans and later Corneel Heymans ran a tight ship at their institute. Their 'managerial style' (Todes, 2002) was paternalistic. As a true pater familias they considered the Heymans Institute and the people working there a second family, a household. ${ }^{16}$ The entire laboratory group supported the idea of the laboratory as a proverbial family throughout the period studied here. 'Professor Heymans has his faults, like all men. But he is a good man, even a great man. . .a good father of his own family and of this laboratory family' (Fox, 1994, p. 85). This was 
an anonymous comment about Corneel Heymans, recorded in 1960. However, it could have been Corneel himself, speaking of his father Jan Frans. So, what was the role of commemoration in this (family) affair? I argue that the internal or private commemorative practices at the Institute internally affirmed the family image and thereby strengthened the internal cohesion of the group. The most important element to these practices was that they included everybody who worked at the Heymans Institute Therefore they were able to smooth out hierarchical differences and to create a joint identity.

\subsection{Parties and Celebrations}

On the occasion of significant birthdays or jubilees of one or another lab member, a party or celebration was organized and attended by the entire Heymans' group. The celebrations, which took place at the institute or a restaurant, were small-scale and only open to laboratory personnel and a few family members. Carefully planned, with prepared speeches and a gift at the end, the structure of these events resembled the official commemorations which will be addressed later on. The style was more informal, though. The programme was not printed and as everyone knew each other, the speeches were anecdotic and personal. There was always something to eat, but whereas the formal receptions with the requisite mingling with guests at official commemorations were hardly ever referred to as eating together, this cozy notion conjuring the imagery of a family eating as a group does crop up in discussions of the internal events. During these private celebrations, references to the daily laboratory practice, the personal habits of the laboratory workers and the handling of laboratory animals were frequent.

Richard van de Velde, hired by Jan Frans Heymans as a caretaker and promoted to the administrative office a few decades later, was celebrated on the occasion of his 25th year of service in 1946. Corneel Heymans opened his speech as follows: 'Upon this intimate, I would say family gathering, it is my great pleasure to express my deepest gratitude to you, Richard, for all the valuable work you've done'. Van de Velde answered to the speeches with great emotion: 'I had never imagined ever becoming the object of a celebration!' He too compared his time at the institute with the ups and downs of family life and referred to his audience as 'our laboratory family'. ${ }^{17}$ Since Richard van de Velde was granted permission to work past his legal retirement age, even his 80th birthday was celebrated at the laboratory. Corneel Heymans and Mister van de Velde sat side by side during the banquet upon this occasion. ${ }^{18}$

Henriette Casier, the female pharmacist whose albums were taken apart so that the pictures could serve as illustrations in another album on the Heymans and whom I originally thought to be a typical illustration of a neglected and unacknowledged member of the lab, was also celebrated in 1955, because she had worked at the laboratory for 25 years. Inside the laboratory she received at least some of the recognition she deserved. Despite recommendations from within the laboratory, it would take another decade until, near to the end of her career, she was also officially acknowledged by the university 


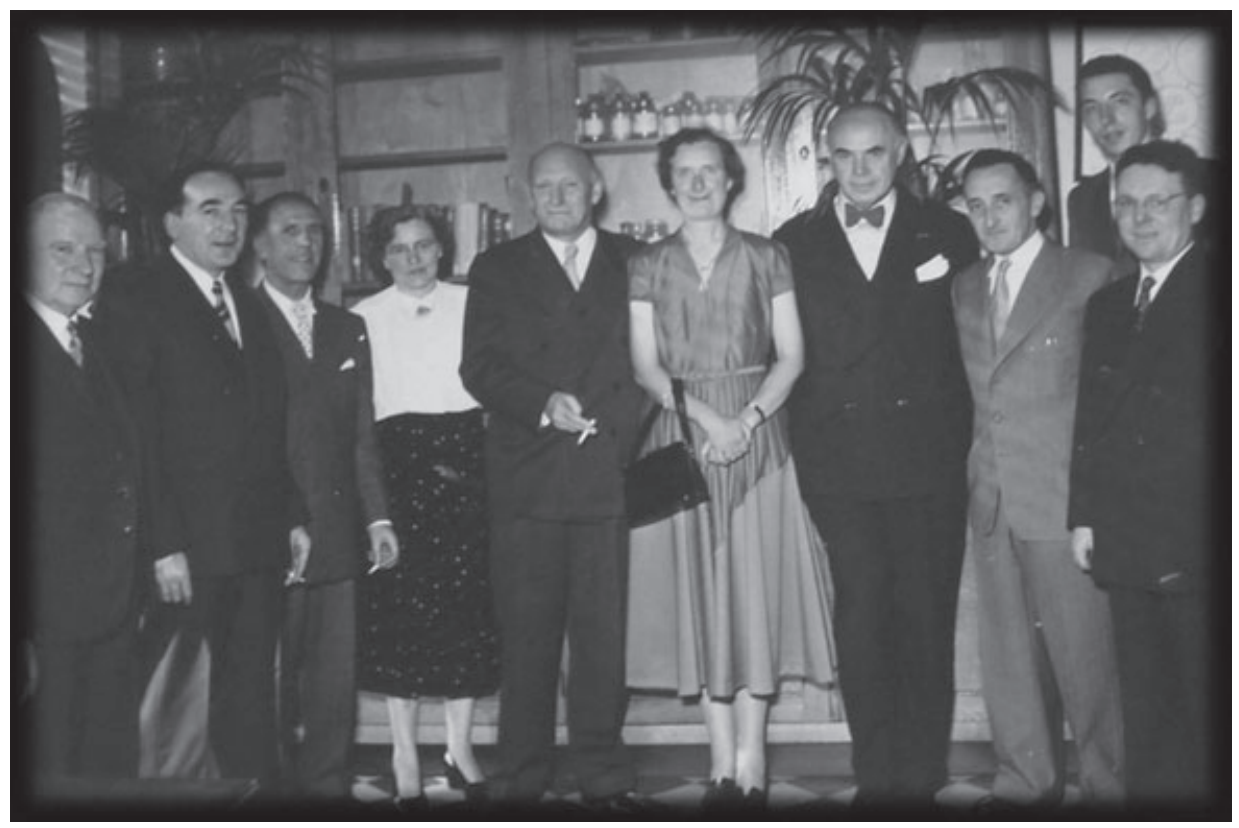

Fig. 3. Celebration Henriette Casier, picture with technical staff, 1955.

and appointed associated professor (Van Der Meersch, 2007, p. 54). Apparently it was easier to take down barriers within the laboratory than outside. Group portraits show Miss Casier amidst her fellow researchers but also with the members of the technical staff. ${ }^{19}$ Two of them, cleaning lady Zulma Maes and Florimond de Vuyst, animal caretaker and laboratory worker, got their own party 5 years later upon their respective retirement and 40th year of service. ${ }^{20}$ The fact that the jubilant was often called by his or her first name, also fits with the informal scheme of internal celebrations. However, only the technical staff were called by their first name. Hence there was definitely a difference in status between the 'family members' that no party or jubilee could take away.

Corneel Heymans turned 70 in 1962. Besides several public manifestations, his birthday was also privately celebrated. The entire Heymans family and the 'laboratory family' gathered in a restaurant in Bruges. Sketches and humorous speeches were delivered by the laboratory personnel: a scientific study on the amount of Coca-Cola consumed at the Institute and other, sometimes even embarrassing anecdotes were told (Corneel Heymans had for instance wrecked an employee's car once and did not notice it until he was already back home). The introduction was very clear: we're together as a family so it must be interesting to the real Heymans' family to be informed of the events and the conviviality at the lab. ${ }^{21}$ Hence it was not the presence of actual family members at these events that made them informal-they were often also in attendance at official commemorations-but the content and the style that made the difference. 


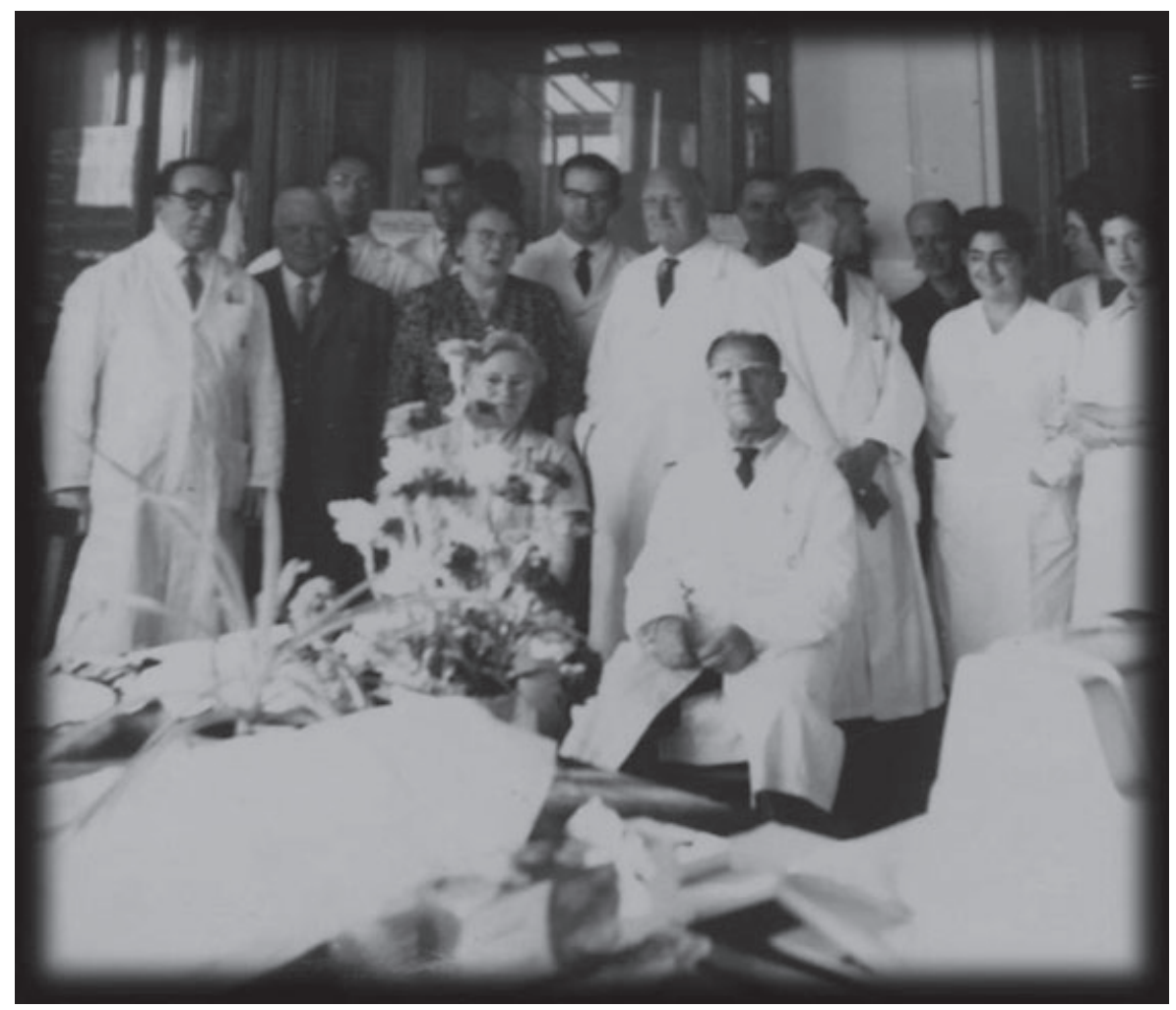

Fig. 4. Celebration of Zulma Maes and Florimond de Vuyst, 1960.

While it is a little exceptional to find such well-documented traces of celebrations for a lab's cleaning lady or technician, as is the case at the Heymans Foundation, it is surely much easier to find records of informal celebrations of a lab's chief or director. Even Pavlov, who kept his many co-workers on a notoriously strict daily laboratory routine, was privately celebrated by his co-workers on the 25th year of his research in 1926 (Todes, 2002, p. 352). It seems that major official commemorative events on behalf of a laboratory director often had an informal counterpart 'for lab eyes and ears only'. It served as a private celebration, but it was also very often an occasion for the director to express his gratitude towards his team (Heilbron and Seidel, 1989, p. 487). In the part on public commemoration it will become clear that during official celebrations the image of the heroic scientist persisted for a long time. Internal celebrations focused more on the achievements of the group and had a warmer familiar atmosphere. Hence for some laboratory members they probably sweetened the bitter pill of lacking public acknowledgement.

Not as much a party but certainly a very important practice at the Heymans' laboratory was the daily tea time, a tradition established under Jan Frans and especially cherished 


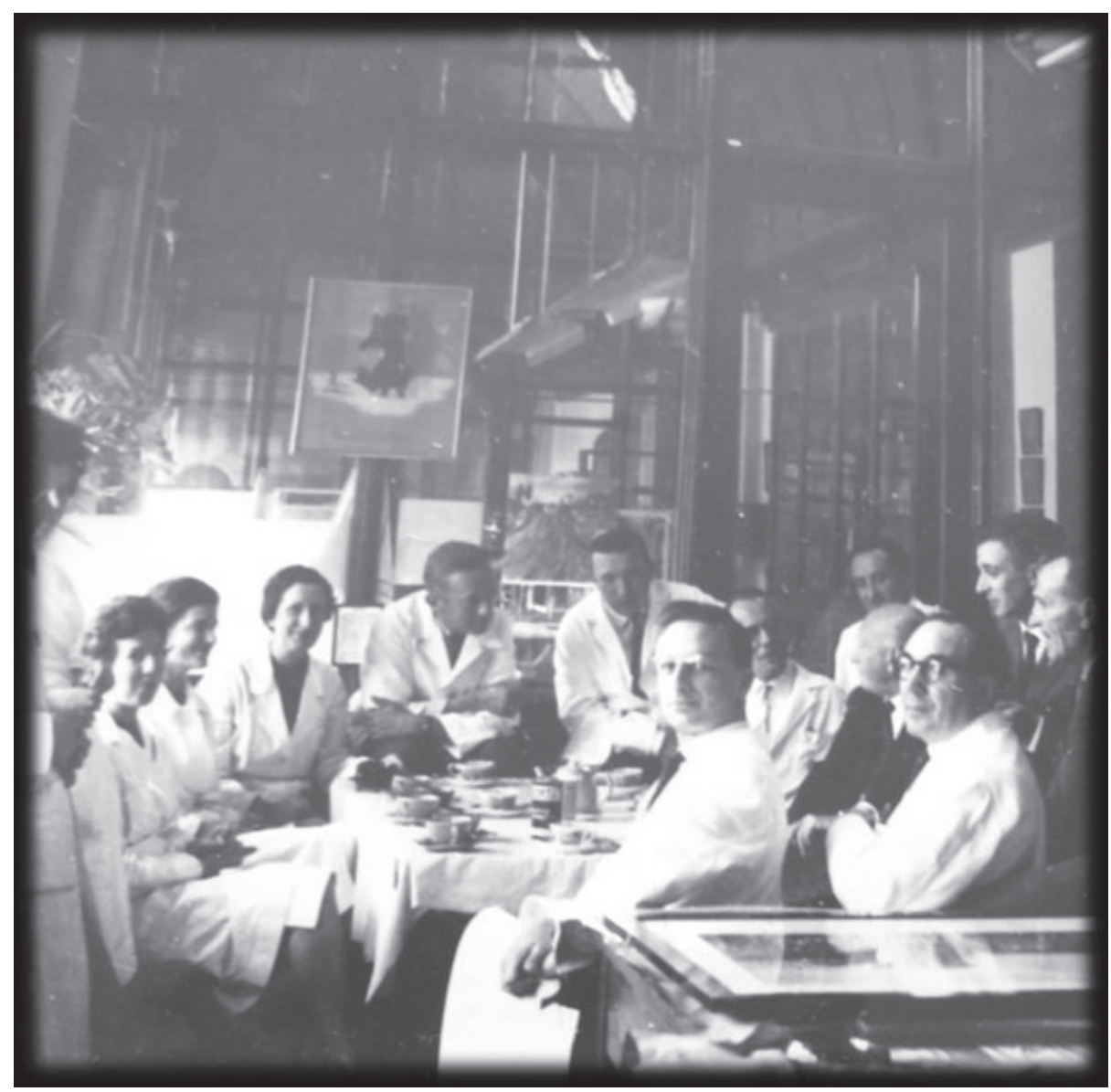

Fig. 5. Tea-time, 1961.

by Corneel Heymans. Daily, at four, everyone drank coffee or tea together. This was also the moment of the day when important news, personal and professional, was announced. Hence sweets, cakes and champagne found their way to the coffee table to celebrate the birth of a child or grandchild, career changes, internal promotions and big events such as the first lesson given as an assistant professor. ${ }^{22}$ These practices were very much part of daily laboratory life and in contrast with the parties mentioned before, the majority of the attendants wore lab coats. Hence being together as a group, talking and often celebrating small personal or professional milestones was deemed important enough to interrupt the scientific work. In retrospect, the surviving members of the laboratory group under Corneel Heymans regretted the loss of these small daily gatherings the most. They were used to illustrate the disappearance of a familiar atmosphere after Heymans' death and the relocation of the lab to a new building (DSI; SVI). ${ }^{23}$ 
These informal celebrations, parties and gatherings were certainly not exclusive to the Heymans Institute. Aside from the celebrations on behalf of a laboratory director previously described, similar events are cited in numerous scientific memoirs and laboratory studies. ${ }^{24}$ Lab Christmas parties, anniversary celebrations, coffee breaks that turned into celebrations with drinks and cake etc. are generally mentioned as a way to exemplify the laboratory's vivid ambiance or informal style in a positive way. Very often when scientists or historians of science want to elucidate the difference between laboratory styles, they mention these seemingly small social events (Cueto, 1994; Pallo, 2010). By identifying them as commemorative practices, they become much more than examples of local lab flavor.

\subsection{Internal Pictorial Commemoration}

Photographs are at the core of the source material for this entire case study. What should not be overlooked, however, is that taking pictures, exchanging them, organizing them etc. can be a commemorative practice in its own right. The enormous collection of unpublished pictures solely taken and conserved for private use in the Heymans lab is the remainder of an internal pictorial commemoration that consists out of two elements. ${ }^{25}$ First of all, the constant recording of the daily activities and personnel members of the laboratory was a commemorative effort. The introduction of the portable camera and the birth of the snapshot, together with the possibility to develop pictures in the lab, made photography a less static and exclusive affair (Collins, 1990; Frizot, 1998; West, 2000). The photographic collection of the Heymans Institute included all the members of the laboratory, even the animal caretakers and the favorite 'labdog' Bobby. ${ }^{26}$ In other laboratories often referred to as anonymous 'invisible hands' or 'laboratory hands' (Doing, 2004; Hentschel, 2008), the inclusion of the technicians and non-academic members of the Heymans Institute stands out. Also the wide range of activities going on at the lab from administration to experimentation, were documented. Group pictures in the garden of the institute were a recurrent event and at every conference in which a delegation of the lab participated, a 'family picture' was taken. ${ }^{27}$ The laboratory group captured who they were and what they did over a period of several decades.

Another element to the informal iconography at the institute was the habit of the Heymanses to ask for a signed picture of everyone who ever worked at the laboratory which were put up on the walls of the office and reception room of the Institute. Miss Casier's picture decorated the walls of the director's office alongside those of A. V. Hill and Carl Wiggers (Fox, 1994). ${ }^{28}$ The official portraits were intertwined with 'family' pictures and cartoons. Hence the director acknowledged his personnel by placing their portrait in the same gallery as famous scientists. Thus in the heart of the laboratory, his office, the two modes of commemoration, private and public, came together. Looking at the informal iconography of the Heymans Institute, it is evident it fits with the scheme 
of a 'homely' feel and an open atmosphere. What else could confirm the household ideal better than a family portrait now and then?

There was no real network of unofficial internal publications at the Institute, such as for example an in-house newsletter described elsewhere by Dominique Pestre (1999). However, written traces of events and personal testimonies were carefully conserved: copies of speeches by technical personnel and personal accounts of the last days of Corneel Heymans, never meant for publication but only for internal commemoration. The very fact that speeches were prepared beforehand shows that the members of the Heymans' lab deemed the internal commemoration important. The careful planning of these internal practices, the inclusion of all lab members and the fact that they were connected to the official commemorative practices all helped to make these internal practices so valuable to the participants.

\subsection{A Family?}

To what extent did the Heymans'group resemble a real family? Besides the obvious role of the director as 'the father' the position of the remaining 'family members' was less defined. Some of the researchers truly regarded the director as a father figure and as a result acknowledged themselves as his proverbial children. Between Corneel Heymans and his successor André De Schaepdryver, for instance, there existed a true fatherly bond. This was confirmed by Mrs. C. Heymans in letters to the latter: '. . you, who are his spiritual son'... 'you know that your family is part of our family'. ${ }^{29}$ Other members of the personnel accepted the general idea of a family without specifying their own role or that of others. It is, for example, hard to imagine that the old Richard van de Velde, who was hired by Jan Frans Heymans and outlived him by many decades, regarded the younger Corneel Heymans as 'a father' during his aforementioned 80th birthday party in 1966. Still van de Velde referred to the lab as 'a big laboratory family'. He spoke in terms of loyalty and going through thick and thin together.

Because the familial context of science is a recurrent theme in the study of women in science (Richmond, 2006, p. 586), one obvious question still remains to be answered: was there a mother in the Heymans' laboratory family? Although I've come across cases were the wife of the professor truly took on a mother role and was acknowledged as such by the laboratory personnel because she would, for example, bring sandwiches to the lab on late nights ${ }^{30}$, this was not the case at the Heymans Institute. The wives of J. F. and C. Heymans were visible during official commemorations but not during daily laboratory life. Besides, Berthe May, Mrs. C. Heymans, had her own career as an ophthalmologist with a thriving practice. Jan Frans Heymans never heartily accepted women students (Elaut, 1977, p. 32) and it was only when Corneel entered the picture that the first female researcher was hired, Miss Casier. One could say that she took on some kind of 'mother-role'. When a new employee was hired, she tried to make him or 
her feel welcome. Because of her childless and single life she was incredibly fond of her 'laboratory family' and carefully documented its evolution in her photo albums.

Although some family roles were well defined and there were actual family ties within the $l a b^{31}$, we can conclude that the abstract idea of a family was more important than factual resemblances to a nuclear or extended family. Hence the rather vague concept of 'family' was foremost an ideal that reflected loyalty and social cohesion. Upon the occasion of Corneel Heymans' 60th birthday party this was nicely summarized by engineer August Delaunois, who had worked at the Heymans Institute since the early thirties: 'We are so to speak a family, striving for the same goal, struggling with the same means' (Elaut, 1952, p. 206). ${ }^{32}$ The importance of the laboratory as an extended family was thus merely a symbolic one and this is quite remarkable. Mostly the 'domestication of science' is studied in the context of a new and upcoming discipline where its founders are forced to fall back on domestic resources and the creation of a family like environment in order to survive (Richmond, 2006). Neither Jan Frans nor Corneel were obliged to do this because they already had a fully equipped and sufficiently funded research laboratory at their disposal. Why then was it felt that there was still a need to refer to a domestic context and what was the related role of commemoration?

The entire laboratory group, from the technicians to the researchers, apparently internalized the family ideal valued so highly by Jan Frans and Corneel Heymans. Indeed, this perceived analogy between the laboratory group and a family eventually became an identity. Through commemorative practices older members of the group expressed their adherence to the family and newcomers where quickly introduced to or merged into the family. Knowing that the Heymans Institute attracted several foreign scholars a year since the early 20 th century makes the family concept even more remarkable. Besides the confirmation of values, the commemorative practices also served to 'introduce' members into the family. Some scholars of management techniques have actually written about similar practices and the family concept as a potential management tool. ${ }^{33}$

Under the directorship of Corneel Heymans, and with the consequent growth of the laboratory team, the internal commemorative practices increased and took on new forms. This related to the new dynamics of science and its celebration as the outcome of teamwork. During the period studied here, science increasingly became a group effort. Internal commemorative practices were an important part of laboratory life and helped to adopt the changing reality of science. Social and gender barriers that could not be overcome outside the laboratory or even during the daily routine, were momentarily softened by the inclusive power of internal commemoration. Lacking public recognition was at least partially compensated by the system of internal commemoration. The above-mentioned testimonies of the recipients of the internal commemorative practices show how highly they valued the unanimous expression of the group's and Heymans' appreciation for their work.

The family metaphor with all its derivates was not unusual in a laboratory context. One famous example, that even includes commemoration as reinforcement of the family 
ideal, is the Pasteur Institute in Paris. It was inaugurated in 1888 and until quite recently was referred to as 'la maison' or 'the house' by its employees. While there exist explicit references to the institute as a family, mostly in memoirs, it is the brilliant analysis of Gerald Geison of the Pasteur Institute as a 'family enterprise' that is most striking (1995, pp. 39, 259-264). The ‘familial tradition' was started by Pasteur himself and continued after his death in 1895. Louis Pasteur and later on his wife (in 1910), were buried underneath the institute in a magnificent crypt. All employees of the Institute, from caretakers to the director, gathered twice a year in the crypt to commemorate the birth and death of the founder of 'our house' (p. 263-264). These events were highly structured with a clear hierarchy, but intended to create a 'family bond', a union above all differences. The family metaphor itself remains an interesting notion in the history of the laboratory that is yet to be explored fully, especially in combination with the often existing real family ties between members of a group. Besides court, state, market and media (Kohler, 2008), the family is a social institution whose values and conventions can be incorporated by the laboratory and vice versa.

\section{Official Commemoration: the Great Scientist and His Research School}

Not all commemorative practices at the Heymans Institute were private. Some commemorative events, publications and portraits clearly were directed towards a larger public. On these occasions all attention was focussed on the laboratory director. Why was public commemoration organized? What was the connection with the private commemorative practices? I argue that public commemoration contributed to the creation of the public image of the 'Ghent School' or the 'Heymans school' and that the idea of the school became an important element in the group's identity.

\subsection{Ceremonies and Celebrations}

Public celebrations are a direct way to commemorate a figure or institute deemed to be important. At the Heymans Institute, as in many similar cases studied e.g. by Pnina Abir-Am (1998a), these official events were organized on the occasion of the retirement of the director, an important anniversary or jubilee. They all had a similar structure and character: speeches were delivered during a formal academic session, a gift was offered to the director and flowers to his wife. The session was followed by a reception or a banquet, very different from the parties at the lab. The staff members of the Heymans' laboratory were part of the organizing committee but were hardly visible during the event. The public was diverse: alumni, academics, administrative and political officials and both Belgian and international guests. A representative of each group usually took the stand. The narrative of the speeches focused on the general scientific accomplishments and the formation of a successful school: at times blasé, with reference to the laboratory as a 
temple for a personified Science, at times nostalgic with anecdotic references to the good old days. The speeches never went into details about scientific or laboratory practice. Abstract and universal values of science were combined with concrete and useful 'people skills' and both were said to have contributed to the success of the school.

Jan Frans Heymans was celebrated upon his retirement in June 1931. Professors from all the institutions of higher education in Belgium and the senior staff of J. F.'s laboratory formed the organizing committee. The Belgian minister of education and the rector and the administrator of Ghent University were honorary chairmen. About a quarter of the attendants were international guests. As a symbolic gesture for Heymans' rich scientific career, the government-bearing in mind that Ghent was a state university-renamed the Pharmacodynamics and Therapeutics Institute, the 'J. F. Heymans Institute' (Heymans, 1932, pp. 1-10). None of the actual employees of the Heymans Institute spoke at the event. Instead the focus was on Heymans' alumni in general. A former student addressed the crowd and acknowledged Heymans as a true 'maître' when he spoke about the severe but rightful treatment he received in the lab and concluded: 'Honored Master, you had achieved your masterly goal and our scientific education was pushed to the limits' (Heymans, 1932, p. 21).

Twenty years after his father's retirement, in March 1952, Corneel Heymans was celebrated on the occasion of his 60th birthday. Coincidentally this also marked the 50th anniversary of the Heymans Institute. The large international event paid homage to the Nobel Prize winner who had successfully continued his father's legacy and had maintained his institute at the centre of pharmacological sciences. ${ }^{34}$ Although the title of the ceremony indicated the half-centennial of the Institute, it was all about Corneel and Jan Frans Heymans. The head of the general pathology and therapeutics lab and previously the longtime co-worker of Corneel Heymans, Jan Bouckaert, concluded:

The laboratory of Professor Heymans became a true school in the proper meaning of that word. It must be told that everyone who spent a certain amount of time there was permanently marked. The influence of the Master at the head of this school was of great importance (Elaut, 1952, p. 204). ${ }^{35}$

The loyalty to director Heymans was remarkable. Bouckaert was personally scarred by the lack of acknowledgement of his contributions to the findings on the carotid sinus. He even left the Heymans Institute and was placed at the head of another department as a sort of compensation. The doors between the physiology and pharmacology division remained symbolically and physically closed until recent years (Fox, 1994). So even with personal tragedies, Heymans' pupils stayed loyal. According to Geison (1995), this unconditional loyalty is one of the most important elements of a lab as a familial enterprise. Hence the family ideals, even adhered to after leaving the institute, also influenced the public commemoration. The public portrayal of a successful and united research school, was deemed important enough to put personal differences aside... just like some families who have their internal disagreements but keep up the appearance of harmony to the outer world. 
Ten years later, in 1962, several ceremonies took place on the occasion of Corneel Heymans' 70th birthday and his retirement. This time the reference to the 60th birthday of the Institute was dropped altogether. Apparently Corneel Heymans had become the personification of the institute's fame so there was no need to state the anniversary of the institute as a separate reason for commemoration. In December Heymans' retirement was celebrated in the auditorium of the Institute. Bouckaert, now rector, made the announcement that the Institute was officially renamed 'J. F. and C. Heymans Institute'. Hence the strong association between the institution and its directors was again acknowledged along with the family continuity. Corneel Heymans was touched by the honors he received and thanked besides his colleagues every individual worker in his laboratory by name and stated: 'All the co-workers of this laboratory, I will not say from the humblest, because there is no humble position at the Institute... Everyone contributes and is necessary' (De Schaepdryver, 1963, p. 114). ${ }^{36}$ Hence the changes in laboratory life as described before became even apparent in the public events.

As opposed to the internal commemorations, that became more numerous as the group grew larger, the public manifestations were a more static given. While Jan Frans Heymans and later on his son Corneel were duly honored for their scientific achievements and excellent personal qualities, the manifestations were also confirmations of the institutional and scientific continuity. During the ceremony in 1962 André De Schaepdryver noted that during the previous seven decades the Heymans Institute had become a true 'temple of pharmacology' (De Schaepdryver, 1963, pp. 109-110). As the new director he certainly benefitted from associating his institute with such superlatives. A very successful era was closed but the new generation was ready to take over. This public confirmation of continuity through the focus on the group as being a research school explains the rather conservative outlook of these events. It was important that the institute was perceived as the constant provider of quality throughout several decades, rather than a few successes. The image of a school with a strong leader proved very powerful in that context.

\subsection{Publications}

Whereas internal parties and celebrations only held meaning for the laboratory group, it was important that the public events and moreover the message they purveyed reached a larger public. This was possible through publications-an article, a booklet or a true Festschrift ${ }^{37}$ - that contained elaborative accounts of the celebration and the honoree's scientific achievements and allowed the dispersion of the research school image on a larger scale. Other commemorative publications, not related to a particular commemorative event such as for instance a necrology or biography, also contained detailed accounts of the scientific accomplishments, often with illustrations. The aforementioned Archives Internationales de Pharmacodynamie et de Thérapie, one 
of the first international journals in its field (Heymans, 1932, pp. 23-24), was also an important tool in the dispersion of commemorative publications. During the century the journal existed it was housed at the Heymans Institute and it had only three consecutive editors: Jan Frans Heymans, Corneel Heymans and André De Schaepdryver. This guaranteed continuity in the content and style of the journal and of course guaranteed exposure if something important happened at the institute.

Corneel Heymans was his father's most loyal admirer and biographer, as was De Schaepdryver for his 'maître'. ${ }^{38}$ Immediately after Heymans's death, he not only organized the Foundation and the Heymans Memorial Lectures, but he also asked several Belgian and international scientists to describe his master as they knew him. In 1972, the personal accounts were bundled into a collective biography (De Schaepdryver, 1972). Hence through these publications the legacy continued, marked by a profound admiration from the successor for his master. They also bore a powerful message: the school had lost its master but would remain successful because the successor had been formed in the same mould as the late leader.

In the case of the Heymanses the commemorative publications meant that a discussion of the isolated head technique could be used to provide an insight into and an anchor for the wider Heymans school. The development and fruitful dispersal of a new technique is traditionally cited as an element of success for a research school (Morrell, 1972; Todes, 2003). The dog became the emblem of the Heymans' group, even though as discussed above the research undertaken in the laboratory was quite broad in scope. The details of the experiments on the dogs, the actual scientific practice and the reality of horrible smells, plaintive barks and monotonous repetitions and failures of the same experiment over and over again, were left unmentioned. The focus was on success and not on the lengthy process of experimentation, nor on the possible competitors who had also done experiments along the same lines (De Castro, 2009a,b). In analogy with the effect of publications on the promotion of the 'Pavlov School' described by Daniel Todes, the celebratory publications studied here, codified the existence of a 'Heymans School' (2003, p. 215).

Two other elements of written public commemoration can be seen in the customs of providing historical accounts on a research topic at the beginning of a survey article and autobiographical accounts of discoveries. They are less striking as being commemorative than the previously cited publications but they are certainly a powerful tool for conveying the image of a sole investigator with many great 'discoveries' up his sleeve (Geison, 1995, p. 268; Abir-Am, 1992, 1998b). To this end Corneel Heymans' accounts of the research that awarded him the Nobel Prize are most striking. The discovery of carotid sinus' function happened 'by accident'. In a highly canonized story Heymans repeatedly referred to the good advice of his father and eagerly used quotes by Darwin and Claude Bernard (Heymans, 1962, 1967). Hence he placed himself and his father in a gallery of universally known scientific heroes. He left many unmentioned: the co-authors of his important papers-all the major articles in the 1930s were co-authored by Bouckaert 


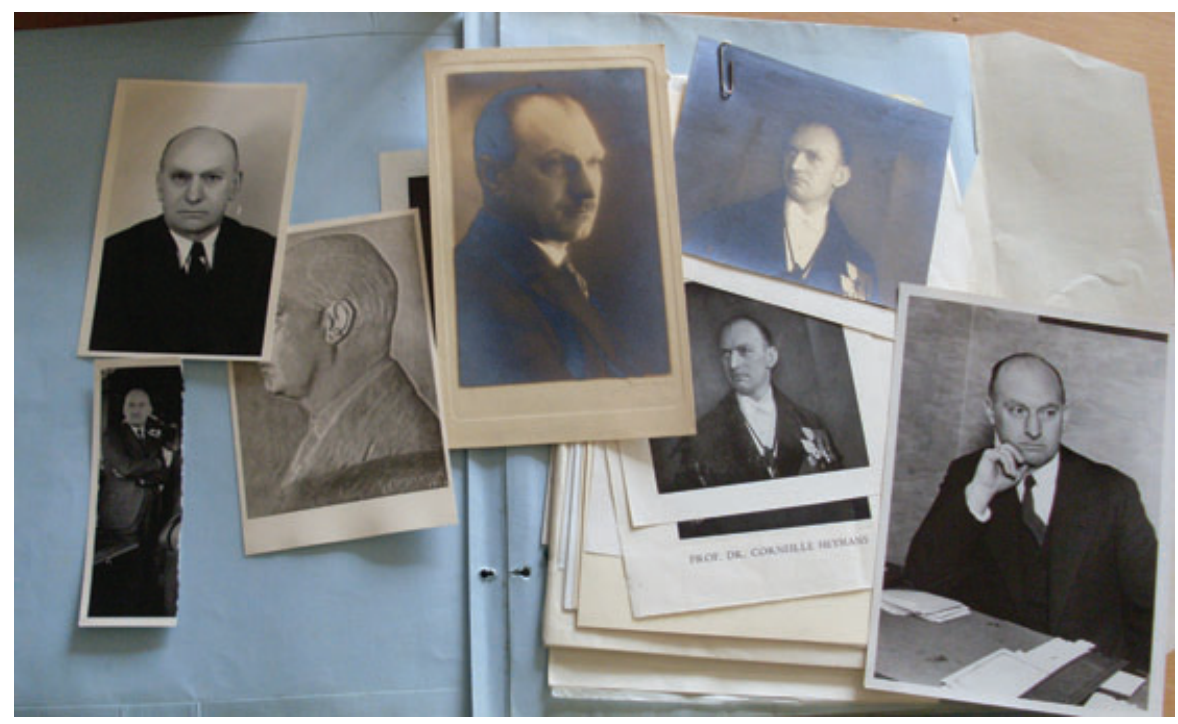

Fig. 6. Collection of official portraits Corneel Heymans.

and others-and colleagues specialized in similar research such as the German Hering and the Spanish De Castro. These were inequalities not even the grandest internal commemorative practices could smooth over, as was indicated by the departure of Bouckaert.

\subsection{Official Iconography}

The commemorative publications concerning father and son Heymans were often illustrated with formal portraits. It has been pointed out how pictures are often used to convey the qualities attributed to the honoree (Abir-Am, 1999a, p. 342). In this case the image of a diligent, sometimes severe scientist and academic certainly was captured in the portraits of father and son Heymans. Wearing a suit or toga, often depicted in profile against an undefined background and even in the pensive 'head-on-hand pose' (Jordanova, 2000, p. 41) they strengthened the inherent formal character of the portrait. This official iconography determined the public image of both J. F. and Corneel. The fact that they were often depicted alone as a solemn, wise professor, reaffirmed the image of an individualistic approach to their scientific accomplishments with no reference to the laboratory group. The formal portraits also served other purposes. The exchange and collection of preferably signed portrait photographs was a widespread commemorative practice in academia during the period studied here. ${ }^{39}$ Both Jan Frans and Corneel Heymans had official, signed photographs made to exchange with friends and acquaintances. In return they collected and displayed the nicely framed pictures of 


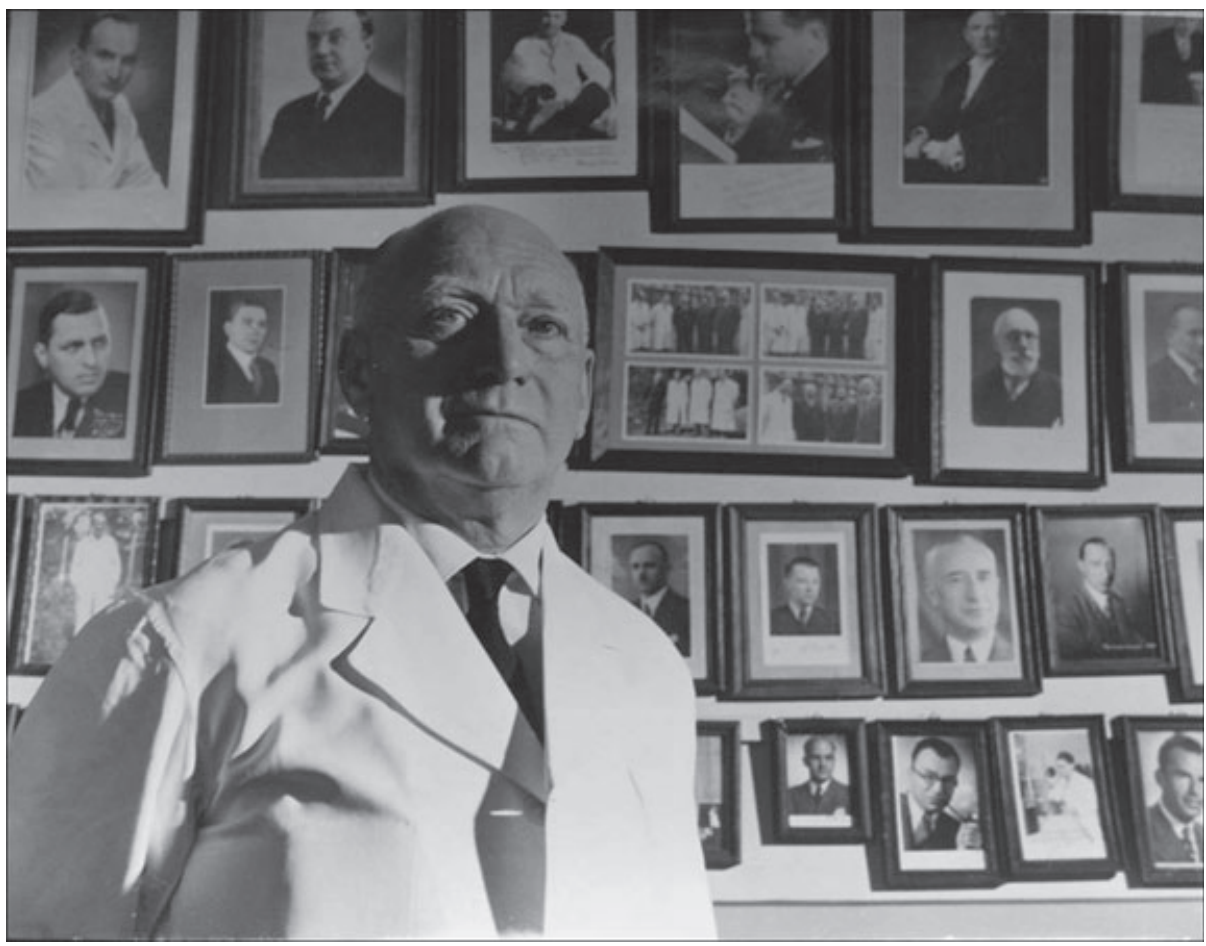

Fig. 7. Corneel Heymans in front of his 'pantheon', s.d.

famous colleagues and heroes of the past. This 'professional pantheon' (Tollebeek, 2008) put on display, symbolized the acknowledgement of heroes and the individualization of their achievements. In Corneel Heymans's office however, the pantheon was, as was noted previously, intertwined with 'family' pictures of staff members and thus it was a visual expression of the intimate connection and delicate balance between official and internal commemoration.

\subsection{A (Research) School?}

Public commemorations at the Heymans Institute focused on the director and thereby conveyed the image of a research school, with one strong leader and an attachment to a distinctive new technique, the isolated head technique. ${ }^{40}$ They did so with great success: the members of the institute were internationally known as the 'Heymans School' or 'Ghent school' as early as the 1920s (De Castro, 2009a). The image of the school was as important to the public relations of the group as it was a fundamental part of their identity. Through the public commemorative practices institutional and scientific continuity was presented to the public. The image of the school was powerful and 
claimed or confirmed a permanent position for the Heymans Institute on the scientific map. The universal personal and scientific values attributed to both father and son Heymans reflected positively upon the authority of the knowledge produced in and by the entire lab. The lab as a whole benefitted from the advantages of a famous director: interesting scientific connections, international visitors etc. (Haddad, 1999; Pestre, 1999). In accordance with the family ideal, Jan Frans and Corneel Heymans both were greatly respected by their team above and beyond personal quarrels. Through public commemorations the researchers and personnel acknowledged their director as a 'master', an important concept in the creation of a professional identity (Dorsman, 2006). The family and community feel celebrated during internal commemorations was completed with a clear professional identity: they were a school, an important one, an elite working under a brilliant leader.

\section{Conclusion: The Many Faces of Commemoration}

The analysis of commemorative practice at the Heymans Institute showed a double network of commemoration. Small-scaled commemorative practices enhanced the cohesion of the group and promoted science as a group effort. Public commemorative practices shaped the group's professional identity and conveyed institutional and intellectual continuity throughout the years. Both types of commemoration contributed to and expressed a collective identity. Throughout the period studied, the laboratory group expanded and scientific practice changed. Commemorative practices proved valuable tools in reconciling apparent contradictions: the acknowledgement of science as a group effort and the public recognition of only one strong leader. The two types of commemorative practices were treated separately for analytical clarity. However, frequent cross references in the text hopefully make it clear that they did not stand apart. In fact one kind of commemoration fed of the other. The co-existence and mutual influence of both public and private modes of commemoration are intriguing and remarkable, but case specific. Both types can exist independently in other laboratory contexts.

Beyond the insights into a very intriguing research group with a preference for dogs and Coca-Cola, with the dog as the ultimate symbol of the scientific genius of father and son Heymans and the soda being the image the group chose to portray daily laboratory life, this article demonstrated that commemoration is part and parcel of laboratory culture. The new category of 'internal commemoration' broadens the concept of commemorative practices and is equally applicable to other cases, as was demonstrated in the second part of the article. The diachronic study of the laboratory-based context of commemoration can shed light on evolving group structure and other scientific practices. Rather than the still interesting and often inspiring question of how science works and what went on in the lab, the study of laboratory-based commemorative practices can also help make a bridge between the inner world of the lab and the broader networks, institutions and contacts on the outside. What is a laboratory? Present day laboratory studies do not 


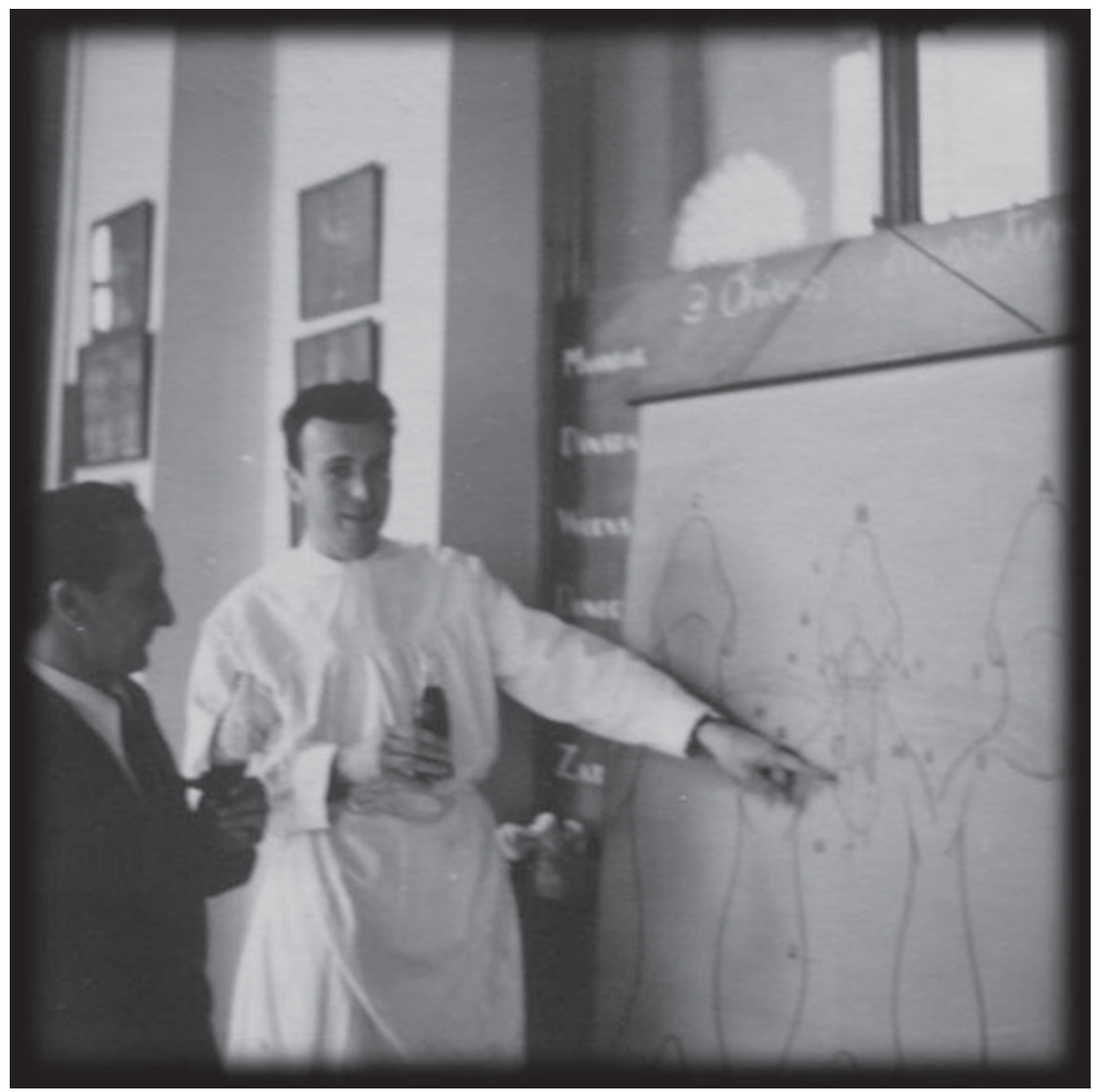

Fig. 8. Dogs and Coca-Cola, 1953.

solely aspire to provide a micro-history of the lab. They try to define the lab as an embedded institution (Gooday, 2008; Kohler, 2008). I believe the study of 'embedded' commemorative practices will not only allow a glimpse of what went on in the lab, but also of how the lab related to the outer world. Moreover, through commemoration the historical agents defined the lab themselves and therefore the study of commemorative practices cannot be ignored from this perspective.

\section{Acknowledgements}

I would like to thank the Heymans Foundation for the generous use of their archive and photographic collections and to the Ghent University Archive. All images are property 
of the Heymans Foundation. I especially want to thank Prof. Em. A. F. De Schaepdryver for his support and insightful stories, as well as Mrs De Smet-Verheecke for the cordial reception and many talks at the Heymans Institute. A shorter version of this paper was presented at the 23rd International Conference of History of Science and Technology in Budapest, Hungary on 1 August 2009.

\section{NOTES}

1. '[Dus de sfeer van het labo was een convivialiteit] Ge ziet dat ook, dat is hier een Hilton he, die muren en al. . .deze kamer, die heb ik een beetje in de sfeer willen houden.'

2. A selection: Abir-Am (1982, 1998a, 1999b), Jordanova (2000), Social Epistemology (1992).

3. Abir-Am (1998a, 1999b), Haddad (1999), Karvar (1998), Sinding (1998b).

4. De Schaepdryver (1990), Wiggers (1958, p. 136), Fox (1994, pp. 68-86).

5. I will not go into the debate 'Why Belgium?' and 'Why Ghent?' any further. An interesting article on this matter, however, was written by Renée Fox, an American sociologist who studied Belgium and its medical research in the second half of the 20th century. It is, not surprisingly, entitled 'Why Belgium?' (1978).

6. I think for instance of the Leuven Physiology Institute (1915-1970) for which very little archival material is conserved but ongoing research consisting of several interviews has revealed frequent commemorative practices.

7. De Schaepdryver (1964), Heymans (1957), Van Bortel (2009a), Van Der Meersch (1998).

8. Plans for the preliminary laboratory at the faculty of arts, GUA, RP, 4A2/4 box 77 (1898/1899), $n^{\circ} 704$.

9. 'Maximum de lumière, minimum de distances; séparation complète entre les locaux pour l'enseignement théorique et ceux pour la pratique expérimentale; communauté maximale enfin entre tous les chercheurs dans le laboratoire'.

10. Correspondence between J. F. Heymans and J. F. Vanderlinden, University Administrator, 1904, GUA, RP, 4A2/4 box 107 (1904-1905) n 202.

11. Heymans and Kochmann (1904), De Somer and Heymans (1912); HFA, AH3, letter by J. Barcroft, 25 April 1932, Tiffeneau (1933, p. 19), Petrucci Jr. et al. (2003).

12. HFA, AH3, J. F. Heymans Condolences 1932.

13. Student and personnel records, unnumbered, 1890-1960, HFA, CC; De Schaepdryver (1990, pp. 65-70); Research topics: Nobel Foundation (1965), Bouckaert (1939).

14. Aside from Corneel Heymans' no-nonsense character he was probably more open to an informal approach due to his experiences in the USA, where labs were notoriously less formal than in Europe (Pallo, 2010).

15. HFA, AH3, correspondence.

16. See previous section and: GUA, RP, 4A2/4 box 107 (1904-1905) $\mathrm{n}^{\circ}$ 202; GUA, RP, 4A2/4 box 109 (1904-1905) n 700b; C. Heymans to University Administration, 11 February, 1937, GUA, Personal File Corneel Heymans.

17. 'Het is een uiterst groot genoegen om eens, na zooveel jaren, hier op deze intieme, bijna familiale bijeenkomst, U, Richard, mijn diepsten dank uit te spreken voor al het zoo kostbare werk dat U hebt gepresteerd'; 'Maar nooit heb ik er aan gedacht dat mijn beurt zou komen!'; Two pictures with subscript 'Huldiging Richard Van de Velde wegens 25 jaren dienst, 1946', HFA, AH; Written notes of speech by C. Heymans, 5 pages, 1946, HFA, AH; Written notes of speech by Richard Van de Velde (1946), HFA, AH; Unnumbered pictures party Richard Van de Velde (1946), HFA, CC.

18. Thirteen pictures with subscript 'Richard Van de Velde 80 jaar, maart 1966', HFA, AH; Written notes of speech by Richard Van de Velde (1966), HFA, AH. 
19. Two pictures with subscript 'Dr. Pharm. H. Casier, 25 jaar op het Instituut, 1955', HFA, AH; Unnumbered picture dated 1955 on the back, HFA, CC.

20. Fifteen pictures with subscript 'Florimond de Vuyst, 40 jaar dienst, en Zulma Maes, op pensioen', HFA, AH.

21. Four pictures with subscript 'Prof. C. Heymans, 70 jaar, Brugge, maart 1962', 12 April 1962 (wrongly dated March), HFA, AH; Written notes of speech by scientific personnel 'Mededeling, gehouden ter gelegenheid van de viering, door het wetenschappelijk personeel van het J.F. Heymansinstitituut, van de 70 verjaardag van Professor C. Heymans, 12 april 1962, La Civière d'Or, Brugge', HFA, AH.

22. Various examples in: HFA, AH and HFA, CC.

23. During research on the Leuven Physiology Institute (1915-1970) I interviewed 11 former employees of that institution. They too, independently, cited the coffee breaks with occasional parties specifically as an interruption of the scientific work and as the ultimate example of a 'familial atmosphere'. Interestingly, when one of them set up his own department, he specifically abolished the coffee break because it was 'a waste of time' and an unnecessary interruption of the scientific work. (Interview Christian de Duve, 15 May 2009).

24. A selection, cited elsewhere in this article: Brachet (2004), Crow and Dove (2000), Heilbron and Seidel (1989), Shropshire (2007), Wilkins (2005).

25. Of course the Ghentians did not have a monopoly on this form of commemoration. Again, it is a matter of identifying certain photographic collections and iconographic traditions as commemorative practices. For example in the studies cited in the previous note, pictures are often used as an illustration to a point and not as objects of study.

26. Various examples in: HFA, AH and HFA, AC1-3; Picture with subscript 'femme à journée avec Boby', 1946, HFA, AC1; Mrs. De Smet-Verheecke remembered how it often happened that out of the many dogs used for experiments, one stood out because he was so cute and hence was kept as a pet or mascot in the lab for a while (SVI).

27. Various examples: HFA, AH and AC (1-3).

28. Box labeled 'Pictures of C. Heymans' contains pictures of C. Heymans in front of his picture gallery, undated, HFA; Two pictures of the portraits against the wall with subscript 'Les chercheurs Belges et Etrangers (du laboratoire)', HFA, AC1.

29. Letter Berthe May (Mrs. C. Heymans) to André de Schaepdryver 16 July 1973 and 5 March 1973, personal collection André De Schaepdryver.

30. Interview Prof. and Mrs. Carmeliet, 2 March 2009.

31. Jan Frans Heymans and Marie Henriette Henning had eight children but only Corneel Heymans followed in his father's footsteps. Corneel Heymans and Berthe May had five children, three sons and two daughters. One of them, Karel Heymans, was a talented medical student but he died at the young age of 18 (Van Bortel, 2009b, p. 370). Only Betty Heymans, one of Corneel's daughters, was at one point employed at the lab, but none of them actually pursued a research career in medicine (HFA, AH, pictures Betty Heymans).

32. 'We vormen trouwens om zo te zeggen een familie, strevend naar eenzelfde doel, strijdend met dezelfde middelen'.

33. Baum (1991), Brotheridge and Lee (2006), Cooper and Gustafson (1981), Ram (2001).

34. Baum (1991), Brotheridge and Lee (2006), Cooper and Gustafson (1981), Ram (2001).

35. 'Zo werd het laboratorium van Professor Heymans een echte school in de volle betekenis van het woord, en het mag worden gezegd dat al diegenen, die er een zekere tijd hebben doorgebracht, een een blijvend kenmerk van hebben behouden'.

36. 'Al de medewerkers van dit laboratorium, ik zal niet zeggen van de nederigste, want er is geen nederige plaats in het Instituut. Iedereen brengt het zijne bij en is onontbeerlijk, van laag tot hoog'.

37. A selection: Heymans (1932), Elaut (1952), liber memorialis (1962). 
38. A selection of publications: Elaut (1952), De Schaepdryver and Bogaert (1998), De Schaepdryver (1990), Heymans (1952), Heymans (1961), Heymans (1963a), Tiffeneau (1933).

39. Baneke (2009), Jordanova (2000), Sange (1998), Tollebeek (2008).

40. Classic studies on different research schools and on the evolution of the notion 'research school' are: Morrell (1972), Servos (1993) and Geison (1993).

\section{REFERENCES}

Heymans institute (1962) Liber memorialis in honor of Prof. Heymans, C., Archives Internationales de Pharmacodynamie et de Thérapie, 139(1-2).

Abir-Am, P.G. et al. (1992) Special Issue: Historical ethnography of scientific rituals, Social Epistemology, 6(4).

Abir-Am, P. G. (1982) How scientists view their heroes: some remarks on the mechanism of myth construction, Journal of the History of Biology, 15(2), 281-315.

Abir-Am, P. G. (1992) A historical ethnography of a scientific anniversary in molecular biology: the first protein X-ray photograph (1984, 1934), Social Epistemology, 6(4), 323-353.

Abir-Am, P. G. (1998a) La mise en mémoire de la science: pour une ethnographie historique des rites commémoratifs (Amsterdam: Éditions des Archives Contemporaines).

Abir-Am, P. G. (1998b) Entre mémoire collective et histoire en biologie moléculaire. Les premiers rites commémoratifs pour les groupes fondateurs, in: P. G. Abir-Am (ed.) La mise en mémoire de la science: pour une ethnographie historique des rites commémoratifs (Amsterdam: Éditions des Archives Contemporaines), 25-74.

Abir-Am, P. G. (1999a) The first American and French commemorations in molecular biology: from collective memory to comparative history, Osiris, 14, 324-372.

Abir-Am, P. G. et al. (1999b) Commemorative practices in science. Historical perspectives on the politics of collective memory, Osiris, 14, i-xii, 1-383.

Abir-Am, P. G. (1999c) Introduction, Osiris, 14, 1-33.

Baneke, D. (2009) The Road to the West goes South: International exchange in astronomy in the early 20th century. Paper presented at the 23rd International Conference of History of Science and Technology held in Budapest, Hungary, 28 July-2 August.

Baum, H. S. (1991) Creating a family in the workplace, Human Relations, 44(11), 1137-1159.

Bouckaert, J. J. (1939) Overzicht van de wetenschappelijke activiteit, deze laatste jaren in het J.F. HeymansInstituut, Wetenschappelijke Tijdingen, 4(8), 240-243.

Brachet, L. (2004) Le Professeur Jean Brachet, mon père (Paris: L'Harmattan).

Brotheridge, C. M. and Lee, R. T. (2006) We are family: congruity between organizational and family functioning constructs, Human Relations, 59(1), 141-161.

Collins, D. (1990) The story of Kodak (New York: Abrams).

Cooper, L. and Gustafson, J. P. (1981) Family-group development: planning in organizations, Human Relations, 34(8), 705-730.

Crow, J. F. and Dove, W. F. (2000) Perspectives on genetics: anecdotal, historical, and critical commentaries, 1987-1998 (Wisconsin: University of Wisconsin Press).

Cueto, M. (1994) Laboratory styles in Argentine physiology, Isis, 85(2), 228-246.

De Castro, F. (2009a) The discovery of sensory nature of the carotid bodies, Arterial chemoreceptors (Dordrecht: Springer), pp. 1-18.

De Castro, F., (2009b) Towards the sensory nature of the carotid body: Hering, De Castro and Heymans, Frontiers in Neuroanatomy, 3(23), 1-11.

De Schaepdryver, A. F. (1963) Hulde aan Prof. Dr. C. Heymans bij zijn emeritaat, De Brug, 7(2), $102-116$.

De Schaepdryver, A. F. (1964) Heymans, Jan-Frans, farmacoloog, Nationaal Biografisch Woordenboek, 356-357.

De Schaepdryver, A. F. (1972) Corneel Heymans. A collective biography (Ghent: Archives Internationales de Pharmacodynamie et de Thérapie).

De Schaepdryver, A. F. (1990) The Heymans institute of pharmacology 1890-1990. 100 years of teaching, research and service (Ghent: Archives Internationales de Pharmacodynamie et de Thérapie). 
De Schaepdryver, A. F. and Bogaert, M. (1998) Corneel Heymans: Zijn leven en werk, Corneel Heymans 1892-1968, herdenking Knokke (Bruges: Catherine Press).

De Somer, E. and Heymans, J. F. (1912) Méthode pour conserver à l'état de survie la tête isolée des animaux mammifières, Journal de Physiologie, 14(6), 1138-1142.

Doing, P. (2004) 'Lab Hands' and the 'Scarlet O': epistemic politics and (scientific) labor, Social Studies of Science, 34(3), 299-323.

Dorsman, L. (2006) Leermeesters, Tijdschrift voor Geschiedenis, 119(4), 454-467.

Elaut, L. (1952) In en om het J.F. Heymans-Instituut was er feest..., Wetenschappelijke Tijdingen, 12(6), 203-211.

Elaut, L. (1977) Drie episoden in de geschiedenis van het geneeskundig hoger onderwijs te Gent (Ghent: University Archives).

Florquin, J. (1974) Ten huize van. . Prof. Dr. Corneel Heymans (Bruges: Orion).

Fox, R. C. (1978) Why Belgium? European Journal of Sociology, 19(2), 205-228.

Fox, R. C. (1994) A Nobel laureate, his "Institute-Home" and "Laboratory Family", in: R. Fox (ed.) In the Belgian château. The spirit and culture of a European society in an age of change (Chicago: Ivan R. Dee), pp. 68-86.

Frizot, M. (1998) Rituals and customs: photographs as memories, in: M. Frizot (ed.) A new history of photography (Milan: Köneman), pp. 747-754.

Geison, G. (1993) Research schools and new directions in the historiography of science, Osiris, 2(8), 226-238.

Geison, G. (1995) The private science of Louis Pasteur (Princeton: Princeton University Press).

Gooday, G. (2008) Placing or replacing the laboratory in the history of science? Isis, 99(4), 783-795.

Haddad, G. E. (1999) Medicine and the culture of commemoration, Osiris, 14(1), 1-18.

Heilbron, J. L. and Seidel, R. W. (1989) Lawrence and his laboratory: a history of the Lawrence Berkeley Laboratory (Berkely: University of California Press).

Hentschel, K., et al. (2008) Unsichtbare hände. Zur rolle von laborassistenten, mechanikern, zeichnern u.a. Amanuenses in der physikalischen forschungs- und entwicklungsarbeit (Stuttgart: GNT-Verlag).

Heymans, J. F. (1932) Huldebetooging J.F. Heymans 7 juni 1931 (Bruges: Catherine Press).

Heymans, C. (1952) J.F. Heymans, Wetenschappelijke Tijdingen, 17(3), 140-152.

Heymans, C. (1961) Les laboratoires de pharmacologie des universités Belges, in: Le mouvement scientifique en Belgique, Vol. 5 (Brussels: Belgisch Verbond der Wetenschappelijke Verenigingen), pp. 313-318.

Heymans, C. (1963a) Ontwikkeling der farmakologie in België, Jubileumboek KAGB 1938-1963.

Heymans, C. (1963b) A look at an old but still current problem, Annual Review of Physiology, 25(1), 1-16.

Heymans, C. (1967) Pharmacology in old and modern medicine, Annual Review of Pharmacology, 7(1), 1-15.

Heymans, C. and Bouckaert, J. J. (1930) Sinus caroticus and respiratory reflexes, Journal of Physiology, 69, 254-266.

Heymans, C., Bouckaert, J. J. and Dautrebande, L. (1930) Sinus carotidien et réflexes respiratoires, Archives Internationales de Pharmacodynamie, 39, 400-448.

Heymans, C., Bouckaert, J. J. and Dautrebande, L. (1931) Au sujet du mécanisme de la bradycardie provoquée par la nicotine, la lobéline, le cyanure, le sulfure de sodium, les nitrites et la morphine, et de la bradycardie asphyxique, Archives Internationales de Pharmacodynamie, 41, 261-289.

Heymans, C., Bouckaert, J. J., Von Euler, U. S. and Dautrebande, L. (1932) Sinus carotidiens et reflexes vasomoteurs, Archives Internationales de Pharmacodynamie, 43, 86-110.

Heymans, C., Bouckaert, J. J. and Regniers, P. (1933) Le Sinus Carotidien (Paris: G. Doin).

Heymans, J. F. and Kochmann, M. (1904) Une nouvelle méthode de circulation artificielle à travers le cœur isolé de mammifère, Archives Internationales de Pharmacodynamie et de Thérapie, 13, 531-538.

Heymans, J. F. and Heymans, C. (1927) Sur les modifications directes et sur la régulation réflexe de l'activité du centre respiratoire de la tête isolée du chien, Archives Internationales de Pharmacodynamie, 33, 273-370.

Jordanova, L. (2000) Defining features: scientific and medical portraits 1660-2000 (London: Reaktion Books).

Karvar, A. (1998) Le centenaire de l'École polytechnique: rites d'une élite nationalesur fond de crise, in: P. G. Abir-Am (ed.) La mise en mémoire de la science. Pour une ethnographie historique des rites commémoratifs (Amsterdam: Éditions des Archives Contemporaines), pp. 191-206.

Kohler, R. (2008) Lab history: reflections, Isis, 99(4), 761-768. 
Morrell, J. B. (1972) The chemist breeders: the research schools of Liebig and Thomas Thomson, Ambix: Journal of the Society for the History of Alchemy and Chemistry, XIX(1), 1-46.

Nobel Foundation (1965) Nobel lectures, physiology or medicine 1922-1941 (Amsterdam: Elsevier Scientific Publishing Company).

Pallo, G. (2010) Between different Worlds: Albert Szent-Gyorgyi and the problem of assistants. Paper presented at the $7^{\text {th }}$ STEP-Conference held in Galway, Ireland, 17-20 June.

Pestre, D. (1999) Commemorative practices at CERN: between physicists' memories and historians' narratives, Osiris, 14, 203-216.

Petrucci Jr, O., Oliveira, P. P. M., Carmo, M. R., Vieira, R. W. and Braile, D. M. (2003) Standardization of an isolated pig heart preparation with parabiotic circulation: methodological considerations, Brazilian Journal of Medical and Biological Research, 36(5), 649-659.

Ram, M. (2001) Family dynamics in a small consultancy firm: a case study, Human Relations, 54(4), $395-418$.

Richmond, M. L. (2006) The 'domestication' of heredity: the familial organization of geneticists at Cambridge University, 1895-1910, Journal of the History of Biology, 39(3), 565-605.

Sagne, J. (1998) All kinds of portraits. The photographer's studio, in: M. Frizot (ed.) A new history of photography (Milan: Köneman), pp. 103-126.

Servos, J. W. (1993) Research schools and their histories, Osiris, 8, 3-15.

Shropshire, W. (2007) Max Delbrück and the new perception of biology 1906-1981 (Bloomington: Authorhouse).

Sinding, C. (1998a) La célébration des découvertes thérapeutiques: des chasseurs de microbes aux manipulateurs de gènes, in: P. G. Abir-Am (eds.) La mise en mémoire de la science. Pour une ethnographie historique des rites commémoratifs (Amsterdam: Éditions des Archives Contemporaines), pp. 125-142.

Sinding, C. (1998b) La grande année Pasteur. Échec du contre culte? in: P. G. Abir-Am (eds.) La mise en mémoire de la science. Pour une ethnographie historique des rites commémoratifs (Amsterdam: Éditions des Archives Contemporaines), pp. 289-310.

Tiffeneau, M. (1933) Notice Nécrologique sur le Prof. J.F. Heymans, Archives Internationales de Pharmacodynamie et de Thérapie, 46(1), 1-30.

Todes, D. P. (2002) Pavlov's physiology factory. Experiment, interpretation, laboratory enterprise (Baltimore: Johns Hopkins University Press).

Tollebeek, J. (2008) Fredericq en zonen: een antropologie van de moderne geschiedwetenschap (Amsterdam: Bert Bakker).

Van Bortel, T. (2009a) Jan-Frans Heymans (1859-1932) en Corneel Heymans (1992-1968), grondleggers van de farmacologie in België, Tijdschrift voor Geneeskunde, 65(7), 319-321.

Van Bortel, T. (2009b) Corneel Heymans (1892-1968): Laureaat van de Nobelprijs voor Fysiologie en Geneeskunde (1938) en medeoprichter van IUPHAR, Tijdschrift voor Geneeskunde, 65(8), 370-363.

Van Der Meersch, A. M. (1998) Heymans, Jan Frans, Nieuwe encyclopedie van de vlaamse beweging $(G-Q)$ (Tielt: Lannoo), 1444-1445.

Van Der Meersch, A. M. (2007) Een universitaire loopbaan voor vrouwen aan de Universiteit Gent (1901-1965): een glazen plafond? (Ghent: Academia Press).

West, N. M., (2000) Kodak and the lens of nostalgia (Charlottesville: University of Virginia Press).

Wiggers, C. J. (1958) Reminiscences and adventures in circulation research (New York and London: Grune \&Stratton).

Wilkins, M. (2005) The third man of the double helix. An autobiography of Maurice Wilkins (New York: Oxford University Press).

\section{Appendix}

GUA: Ghent University Archives, Sint-Pietersnieuwstraat 25, Ghent, Belgium.

HP: Heymans Papers.

RP: Rectoral Papers.

HFA: Heymans Foundation Archives, De Pintelaan 185, Ghent, Belgium. 
AH: Album Heymans Institute

AH1: Album J. F. and C. Heymans 1

AH2: Album J. F. and C. Heymans 2

AH3: Correspondence J. F. and C. Heymans

AC: Album Casier (1-3)

CC: Collection Casier (the pictures in this collection, aprox. 350, are unnumbered and contained loose in a paper binder)

The items of the HFA are not professionally archived. Hence all other pieces, that are not numbered or put in folders, are described individually.

DSI: De Schaepdryver Interview (2009): Interview Prof. Em. André De Schaepdryver in the main room of the Heymans Foundation at the University of Ghent on 15 May 2009.

SVI: De Smet-Verheecke Interviews: Various informal conversations with Mrs. De SmetVerheecke, secretary at the Heymans Institute since 1965 up until this date, in June and July 2009 during research at the Heymans Foundation. 